\title{
Picking up the pieces: the digital reconstruction of a destroyed holotype from its serial section drawings
}

\author{
Julien Benoit and Sandra C. Jasinoski
}

\begin{abstract}
Serial grinding, a popular but destructive technique in the early twentieth century, allows for the detailed tomographic study of vertebrate fossils. Specimen BP/1/1821 (formerly $\mathrm{BPI} / 1 / 346$ ) is a procynosuchid cynodont (Therapsida) that underwent serial grinding by A.S. Brink in 1961, resulting in a detailed and insightful study of its skull anatomy. However, BP/1/1821 was also designated by Brink as the holotype, and only specimen, of a new (now a junior synonym of Procynosuchus delaharpeae) species of cynodont: 'Scalopocynodon gracilis'. This species has subsequently been recognised as a junior synonym of Procynosuchus delaharpeae, but the destruction of a holotype remains an irreversible loss. Brink built an enlarged wax model from the serial sections, but it is degrading rapidly. In this article, we explain how we retrieved Brink's original drawings of the sections, and how we were able to build a new digital model of this specimen using a scanner, virtual stack alignment, and 3D imaging. Comparison with previously published drawings demonstrates the accuracy of this digital model. With a $3 \mathrm{D}$ printer, we then re-created a more accurate replication of BP/1/1821 with resin. This life-sized replica now helps to complete the collections of the Evolutionary Studies Institute (University of the Witwatersrand, Johannesburg, South Africa) and replaces the long lost original specimen. The possibility to re-use these old data for palaeontological research is also addressed.
\end{abstract}

Julien Benoit. Evolutionary Studies Institute (ESI); School of Geosciences, University of the Witwatersrand, PO Wits, 2050, Johannesburg, South Africa; School of Anatomical Sciences, University of the Witwatersrand, 7 York Road, Parktown, 2193, Johannesburg, South Africa. julien.benoit@wits.ac.za Sandra C. Jasinoski. Evolutionary Studies Institute (ESI); School of Geosciences, University of the Witwatersrand, PO Wits, 2050, Johannesburg, South Africa. sandra_jas@hotmail.com

Keywords: Cynodont; Serial Grinding Tomography; Therapsida; Digitization; Curation; Skull

Submission: 12 February 2016 Acceptance: 26 July 2016

Benoit, Julien, and Jasinoski, Sandra C. 2016. Picking up the pieces: the digital reconstruction of a destroyed holotype from its serial section drawings. Palaeontologia Electronica 19.3.3T: 1-16

palaeo-electronica.org/content/2016/1478-reconstructing-scalopocynodon

Copyright: () September 2016 Society of Vertebrate Paleontology. This is an open access article distributed under the terms of the Creative Commons Attribution License, which permits unrestricted use, distribution, and reproduction in any medium, provided the original author and source are credited.

creativecommons.org/licenses/by/4.0/ 


\section{INTRODUCTION}

For each palaeontological animal species named, the International Code of Zoological Nomenclature (ICZN) stipulates that a holotype must be defined in order to serve as a reference for future works (ICZN, 1999). As a consequence, the designation of a type specimen is, by far, the most critical step when creating a new taxon, and the destruction of a type specimen constitutes an irreplaceable loss to science. Under South Africa's heritage laws, this also represents a failure to protect part of the National Estate. Unfortunately, this is what happened to the holotype of the South African procynosuchid cynodont 'Scalopocynodon gracilis' (this taxon name will thereafter be enclosed in quotation marks to reflect the fact that it is now considered a junior synonym of Procynosuchus delaharpeae [Hopson and Kitching, 1972]), which was destroyed during a serial grinding tomographic (SGT) study by Brink (1961), the author of the taxon. Although the SGT study allowed him to exquisitely describe the skull in great detail, this unfortunately led to the definitive loss of this unique piece of South African fossil heritage. Given the extraordinary wealth of fossils coming from the time-expansive Karoo sedimentary succession of South Africa (Rubidge and Sidor, 2001), South African therapsids were among the first and the most extensively studied species using this technique, even until recent time (e.g., Sollas and Sollas, 1914; Olson, 1937, 1944; Kermack, 1970; Fourie, 1993; Maier and van den Heever, 2002; Sigurdsen, 2006), because some of them are known from dozens or even hundreds of specimens. However, before it was synonymized with $P$. delaharpeae, 'Scalopocynodon gracilis' was represented by only one specimen (previously numbered BP/1/346, now BP/1/1821).

The technique SGT was invented by Sollas (1904) and was intended to revolutionize the way in which palaeontologists study their fossils (Simpson, 1933; Sutton, 2008). During SGT, a special device is used to grind the specimen at thin and regular intervals. At every step, a tomogram (i.e., drawing made either from a photographic plate or a projected image) or a photograph of the section is made so that the corpus of tomograms obtained illustrates the internal anatomy of the specimen in sequential slices (Sutton, 2008; see Appendix 1). Using this technique, it became possible to describe in great detail the internal anatomy of fossils. At that time, the only alternative was to wait for discoveries of naturally preserved internal structures, such as an endocast of braincase and bony labyrinth (e.g., Case, 1914; Dart, 1925; Cox, 1962; Jerison, 1973; Quiroga, 1984; Court, 1992; KielanJaworowska et al., 2004), isolated bony elements of the chondrocranium (e.g., Benoit et al., 2013a, $2013 \mathrm{~b}$ ), or to undergo a "dissection" of the structure of interest (Dechaseaux, 1974; Gould, 1989).

Serial grinding tomography was used in the twentieth century and led to a substantial improvement of knowledge about the deep internal morphological structure of extinct vertebrates (e.g., Sollas and Sollas, 1914; Stensiö, 1927; Jarvik, 1942, 1954). The technique also allows for the 3D reconstruction of the fossil using wax, cardboard, or polystyrene sheets that are cut into the shape of each fossil slice and stacked sequentially (Sutton, 2008; Cunningham et al., 2014). This kind of tomography is the methodological predecessor of the modern-day computer-assisted tomography (CT scan). Curiously, although alternative methods were invented to preserve the slices of the specimens on plates, and though non-destructive X-ray radiography was performed on fossils as early as the end of the 19th century (Branco, 1906), and CT scans as early as the end of the 1970s (Conroy and Vannier, 1984), SGT enjoyed great popularity and was applied in vertebrate palaeontology for a very long time with noticeable success (e.g., Sollas and Sollas, 1914; Stensiö, 1927; Jarvik, 1942, 1954; Olson, 1937, 1944; Fourie, 1993; Maier and van den Heever, 2002; Sigurdsen, 2006; and reviewed in Sutton, 2008; Cunningham et al., 2014; Laaß and Schillinger, 2015). Nevertheless the destructive aspect of this approach has generally been implemented in well- sampled vertebrate taxa, where large numbers of specimens limited the impact of the destruction (e.g., the South African dicynodonts [Sollas and Sollas, 1914; Fourie, 1993], some Devonian fishes [Stensiö, 1927; Jarvik, 1942, 1954], the well-sampled artiodactyls Merycoidodon, Poebrotherium, and Leptomeryx [Whitmore, 1953] and squalodontid whales from North America [Luo and Eastman, 1995], and multituberculate mammals from Mongolia [KielanJaworowska et al., 1986]).

Researchers and curators remained reluctant to carry out SGT most of the time because the irreversible damage to fossils is contrary to the principles of heritage conservation. Moreover, the specimens selected for the technique tend to be well preserved since researchers want the best for their study in order to extract maximum information by destroying a minimum of fossils. The technique can be very time-consuming, sometimes taking years to carry out (Jarvik, 1942, 1954; Sutton, 
2008; Cunningham et al., 2014). Other methods were invented to inspect the interior of fossils without completely destroying them, such as midline sawing in order to prepare the interior of a skull, or tungsten microtomy which enable preservation of at least part of the original material, but they were expensive, time-consuming, and their use was not as widespread (Sutton, 2008; Cunningham et al., 2014). Only non-destructive CT imaging has replaced SGT in vertebrate palaeontology, but not prior to the 1990s.

One of the most dramatic losses as a result of an SGT study was the destruction of the holotype specimen of 'Scalopocynodon gracilis'. Brink intended to use serial grinding tomography (SGT) in order to study BP/1/346, the only known skull of a new genus and species he named in the same article (Brink, 1961). However, it appears that the destruction of a holotype was not intentional: Brink at first believed the specimen represented a common therocephalian (Scaloposaurus) and did not realize that it was a new species of cynodont until the secondary palate became evident in the sections (Brink, 1961, p. 119). At that point of realization, Brink (1961, p. 119) decided "to reconsider the implications of this misinterpretation ... It was also considered that the specimen might prove to be the type of new species of Procynosuchid, and careful thought was given to the implications of destroying a type. At this stage it was decided to reconstruct in wax the anterior half of the skull, as far as it was then sectioned. The resultant model, although exhibiting some peculiar features, suggested that the specimen very likely represented a juvenile stage of an existing species of Leavachia, Procynosuchus, or Galecranium, and it was decided to proceed with the sectioning."

The specimen BP/1/346 is thus to be considered a lost holotype and 'Scalopocynodon gracilis' could be considered a nomen dubium. However, because Brink thoroughly described the morphology of the specimen and reconstructed a wax model (still available at the Evolutionary Studies Institute [ESI, University of the Witwatersrand, Johannesburg, South Africa]), Hopson and Kitching (1972) were able to synonymize 'Scalopocynodon gracilis' with Procynosuchus delaharpeae. The recognition of 'Scalopocynodon gracilis' as a junior synonym of Procynosuchus delaharpeae, a welldocumented species, minimized the consequences of the loss of BP/1/346. However, as BP/1/346 will remain a holotype in perpetuity, its loss remains unfortunate, especially since a delicate wax model will not last as long as the original fossil.
Here we present a new, digital reconstruction of $\mathrm{BP} / 1 / 346$ based on the original hand-drawn tomograms by Brink (1961). This 3D virtual model is compared with the wax model and the description of the original specimen published by Brink (1961). This comparison revealed that the wax model is deformed, inaccurate in places, and has already been extensively restored. The purpose here is neither to resurrect the taxon 'Scalopocynodon gracilis', nor it is to redescribe BP/1/346 since complete and comprehensive descriptions of this specimen as well as Procynosuchus delaharpeae have already been published (Brink, 1961; Kemp, 1979). Instead, the goal here is to compare the original description by Brink (1961), the wax model, and the digital model of BP/1/346 in order to discuss the accuracy and reliability of this new model. Finally, we introduce the new 3D printed model of $\mathrm{BP} / 1 / 346$ based on the digital model, which now enriches the Karoo holotype collection of the ESI with a restored representation of the long lost holotype.

\section{MATERIAL AND METHODS}

Brink (1961) clearly detailed how he reconstructed the wax copy of specimen BP/1/346. Drawings of the lateral, dorsal, and ventral views accompanied the description, as well as a selection of 14 coronal sections and the reconstruction of a sagittal section (Brink, 1961, figures 33-35). Since 1961, the wax model was kept in the Karoo holotype room at the ESI under the catalogue number BP/1/1821. The drawings received the same number, but they were labelled "Therocephalian" (Figure 1) and were not associated with the wax model. The drawings of the serial sections and the ventral and dorsal views of $\mathrm{BP} / 1 / 346$ were recovered in a plastic bag catalogued BP/1/1821. Drawings of the lateral view and sagittal section were not recovered. The cover of the serial sections stated that the drawings were those of a therocephalian skull possibly belonging to Aneugomphius (now synonymized with Theriognathus [Sigurdsen et al., 2012], but note that during the early stages of serial grinding Brink believed that it was a Scaloposaurus [Brink, 1961, p. 119]) (Figure 1 ), which could explain why those drawings were not stored along with the wax model. Despite this, we are confident that the drawings are those made by Brink in 1961 of BP/1/346 because: i) they are identical to Brink's (1961) published figures and to the wax model (Figure 2), ii) the cover is labelled with the specimen number 346 (Figure 1), and iii) it is signed with Brink's name and initials (Figure 1). 


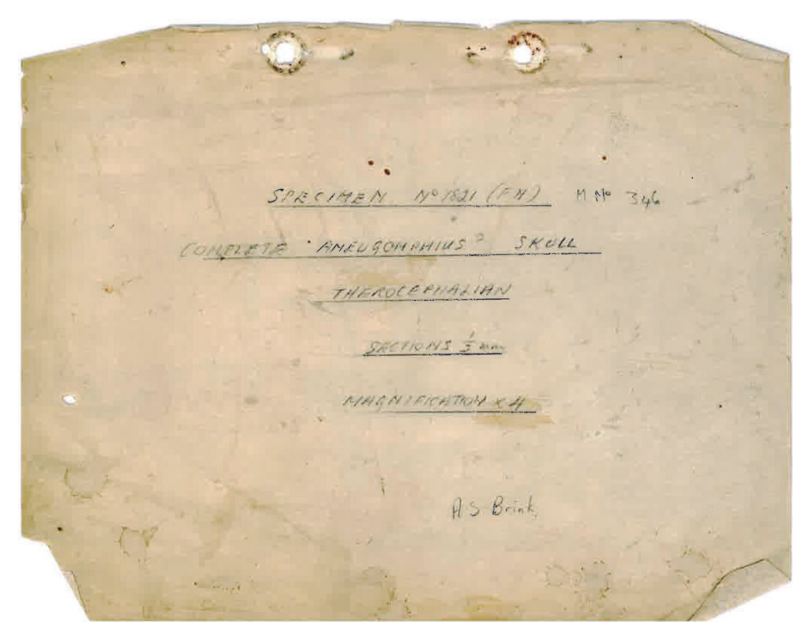

FIGURE 1. The label on the first page of the serial section drawings. It is written "Specimen $\mathrm{N}^{\circ} 1821$ (FN). $\mathrm{MN}^{\circ}$ 346. Complete Aneumogomphius? skull therocephalian. Sections $1 / 2 \mathrm{~mm}$. Magnification $x 4$." The document is signed "A.S. Brink". Abbreviations: FN, Field Number; $\mathrm{MN}^{\circ}$, Museum Number.

Today, BP/1/346 now refers to a dicynodont specimen, the holotype of Brachyuraniscus merwevillensis (transferred to Pristerodon by King and Rubidge, 1993), which was formerly numbered BP/ $1 / 218$ and the skull of which is now ironically lost (King and Rubidge, 1993). Consequently, in order to avoid confusion, and since the original BP/1/346 cynodont specimen no longer exists, all the material formerly referred to 'Scalopocynodon gracilis' is hereby designated the number BP/1/1821.

All 116 serial tomograms drawn by Brink (1961) are present. They were drawn with the help of an episcope (which projected an image of the specimen onto a sheet of mounted paper) with a four times magnification (Brink, 1961; Appendix 1). Though the paper is becoming yellowish, the pencil tracings are still clearly visible (Appendix 1). As stated in his article, Brink (1961) found a way to grind the entire specimen (usually the last centimeters are shredded during the grinding process); hence the 116 slices represent the entire specimen.

The drawings of the serial sections were scanned with a standard office scanner. The pictures were then converted into 8 bit grayscale images and their contrast was improved using Fiji 64bit (Schindelin et al., 2012). The slices were aligned and stacked into a single RAW file using the "Align slices in stack" function of the Template Matching plugin under Fiji 64bit. Brink (1961) drew the serial sections with a four times magnification in order to reconstruct the wax specimen four times larger than the original. Here, the images were rescaled to natural size using the measurements given by Brink (1961). The digital reconstruction of $\mathrm{BP} / 1 / 1821$ was obtained using threshold and manual segmentation in Avizo 8 software (VSG). The digital model (Figure 3, Appendix 2) is a direct reconstruction of the slices drawings. No further efforts to cosmetically improve the digital model, such as resampling the slices or surface smoothing, were performed. Features that were crossed out on the drawings were not considered during segmentation (e.g., section 14, see Appendix 1). The specimen was printed in 3D using Zprinter 450 (Figure 4). This 3D printed model represents the first accurate, life-sized reconstruction of BP/1/ 1821 in 55 years.

\section{DESCRIPTION}

The digitization of the serial section drawings of $\mathrm{BP} / 1 / 1821$ illustrates how much information was lost during the SGT process. The slice edges are prominent (Figure 3 ), and it is clearly apparent that the slice intervals were too thick. Brink (1961) admitted that slicing the specimen every $0.5 \mathrm{~mm}$ was not enough for such a small skull (skull length: $60 \mathrm{~mm}$ ) and a lot of information was lost. The jagged aspect of the digital specimen may also partly reflect the subjectivity of Brink's original handdrawn tomograms. In effect, the apparent lack of alignment of some of the slices on what should be smooth surfaces (see Appendix 1) implies some degree of inaccuracy in the original drawings. Nonetheless, Brink clearly drew the sutures of most identifiable cranial bones, which can thus be digitally extracted and isolated (Figure 5).

Having access to the complete series of sections of the skull is quite useful. One can determine if some of the sutures remained patent or became obliterated, which might be an important indicator of ontogenetic age in basal cynodonts (see Jasinoski et al., 2015). In addition, access to the complete set of sections (Appendix 1) allows for reinterpretation of the identification of bones and sutures and can highlight discrepancies with the published sections (Brink, 1961, figure 35) and/or the reconstructed skull (Brink, 1961, figures 33-34). This comparison showed that a few of the sutures in Brink's published sections are not illustrated in his original drawings. For example, the parietalparietal suture anterior and posterior to the pineal foramen is absent from his original drawings (Appendix 1), but it is present on his published sections (Brink, 1961, figure 35, sections 84, 100). Therefore, it remains equivocal whether this mid- 

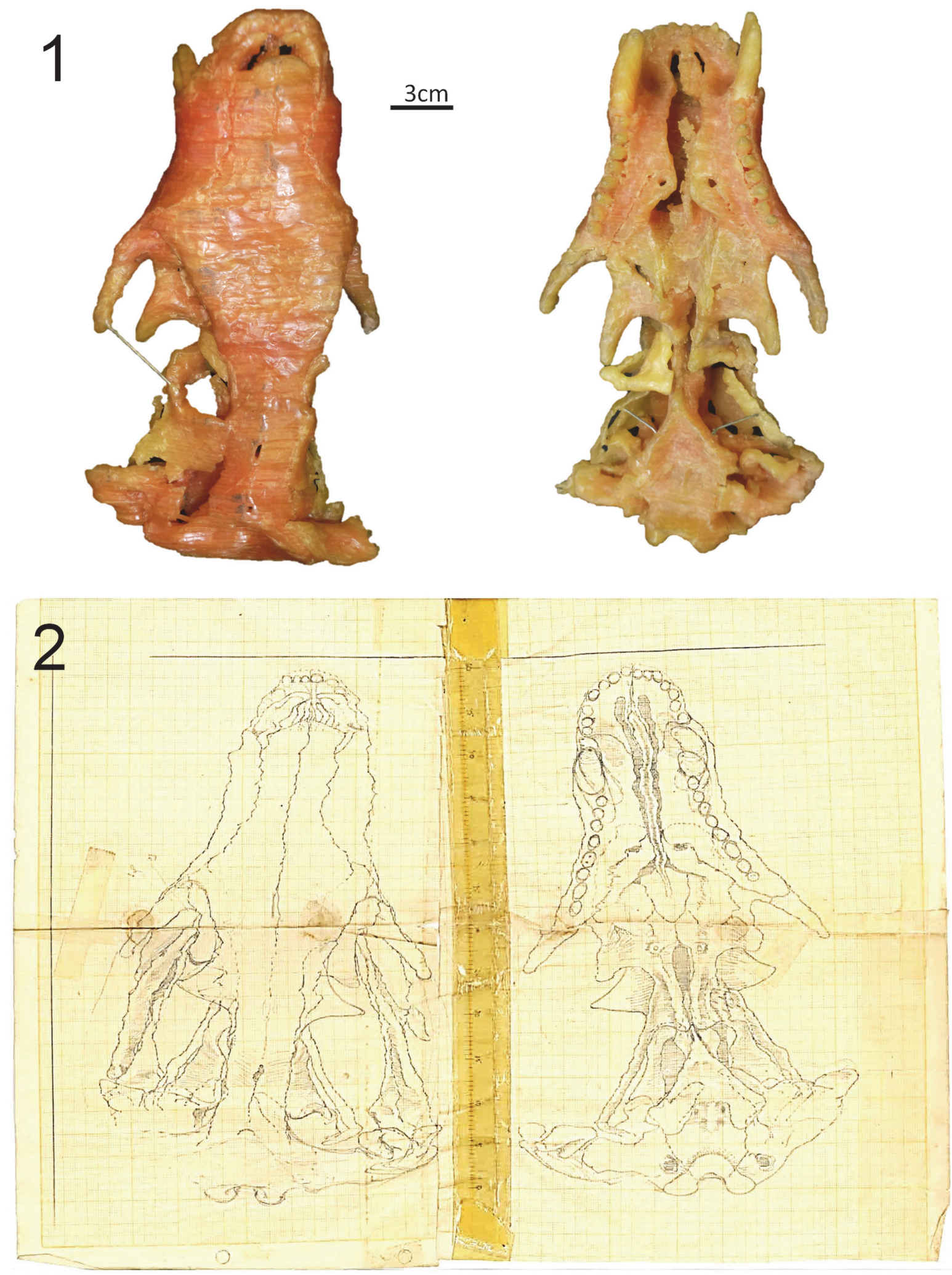

FIGURE 2. Comparison of the different reconstructions of $B P / 1 / 1821$ in dorsal (left) and ventral (right) views. 1, the wax model; and 2, the original illustrations by Brink, found with the serial section drawings. 


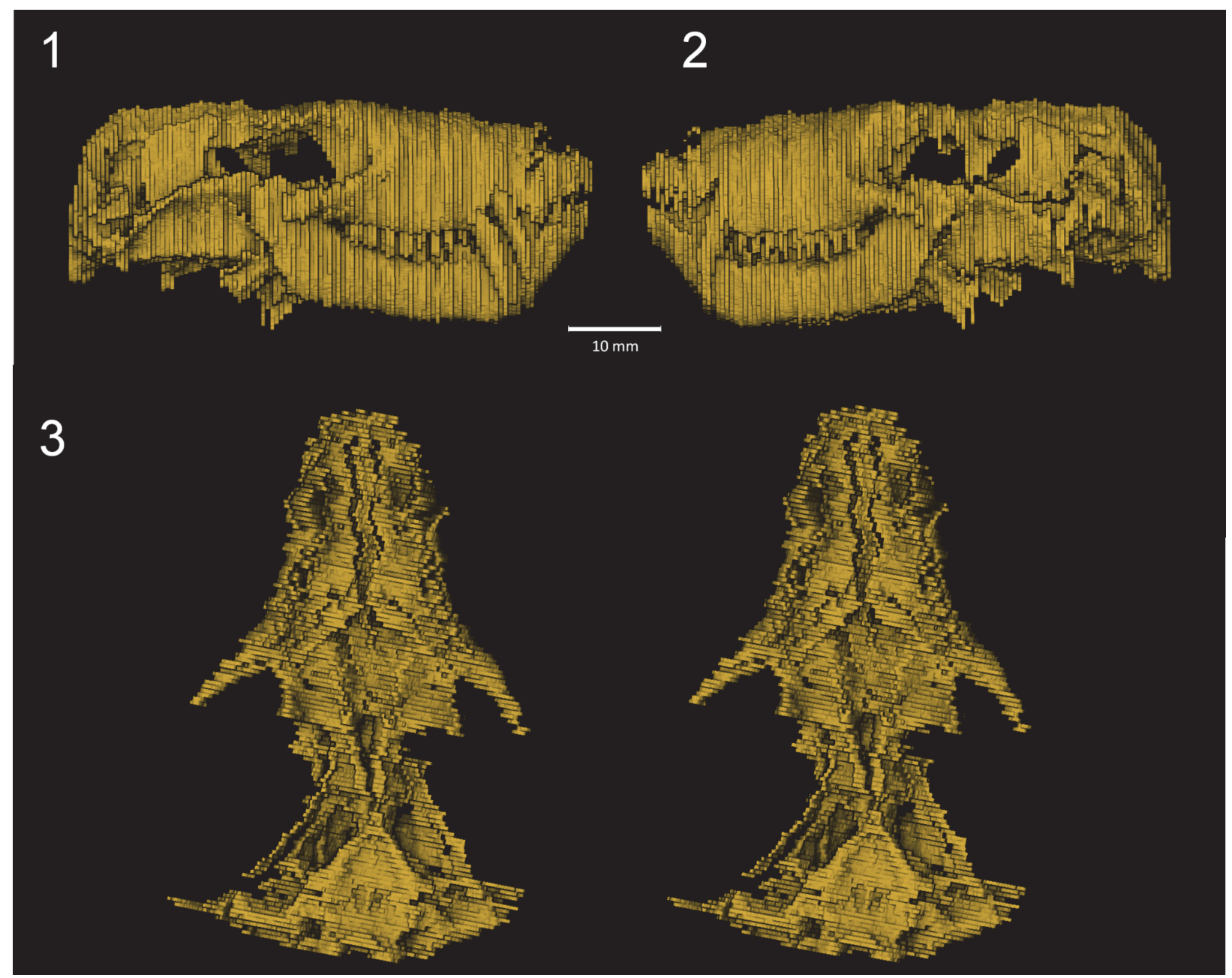

FIGURE 3. The digital model in (1) right lateral, (2) left lateral and (3) ventral view in stereopairs. Scale bar equals 10 $\mathrm{mm}$. See also the supplementary video in Appendix 2.

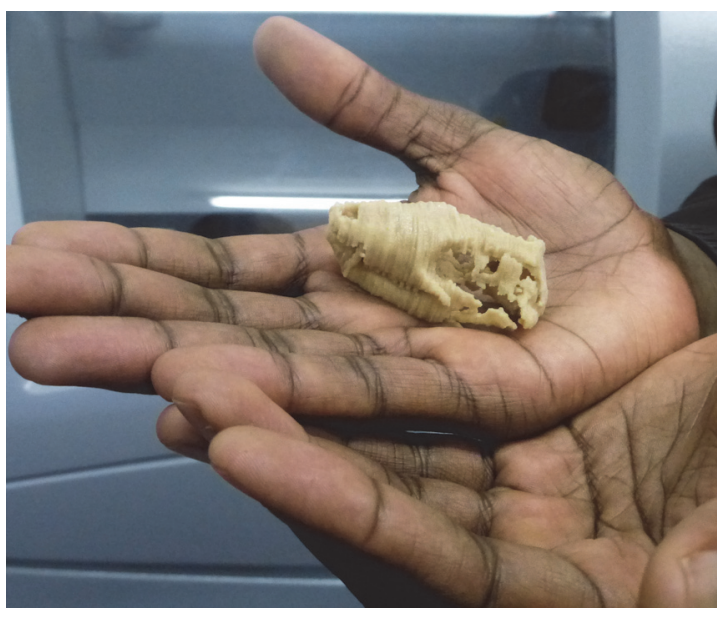

FIGURE 4. The slices of specimen BP/1/1821 finally put back together again, as seen in the hands of the CT scan facility technician $\mathrm{K}$. Jakata (ESI). This 3D printed model is the first time in 55 years that $\mathrm{BP} / 1 / 1821$ has been accurately reconstructed at life-size. line suture on the skull roof was partially obliterated. On the contrary, the nasal-frontal suture is absent (see Figure 5.1) from both the published and original drawings of the sections, but this might be due to the longitudinal orientation of the interdigitations that is difficult to interpret in coronal section, or the thicker sections did not intersect the region of the suture, or weathering prevented detection of the suture (see Brink, 1961, p. 123). Brink estimated the position of this suture on his reconstruction of the skull (Brink, 1961, figure 33A). As for bone identifications, Brink's (1961, figure 35) section 102 through the labelled supraoccipital bone ('so') might actually be through the parietal or the interparietal. Additionally, the articular ('art') on section 106 (Brink, 1961, figure 35) appears to be the quadratojugal (Appendix 1; Figure 5.2).

Apart from the size difference, the digital model and the wax model (Figure 6) look quite dif- 


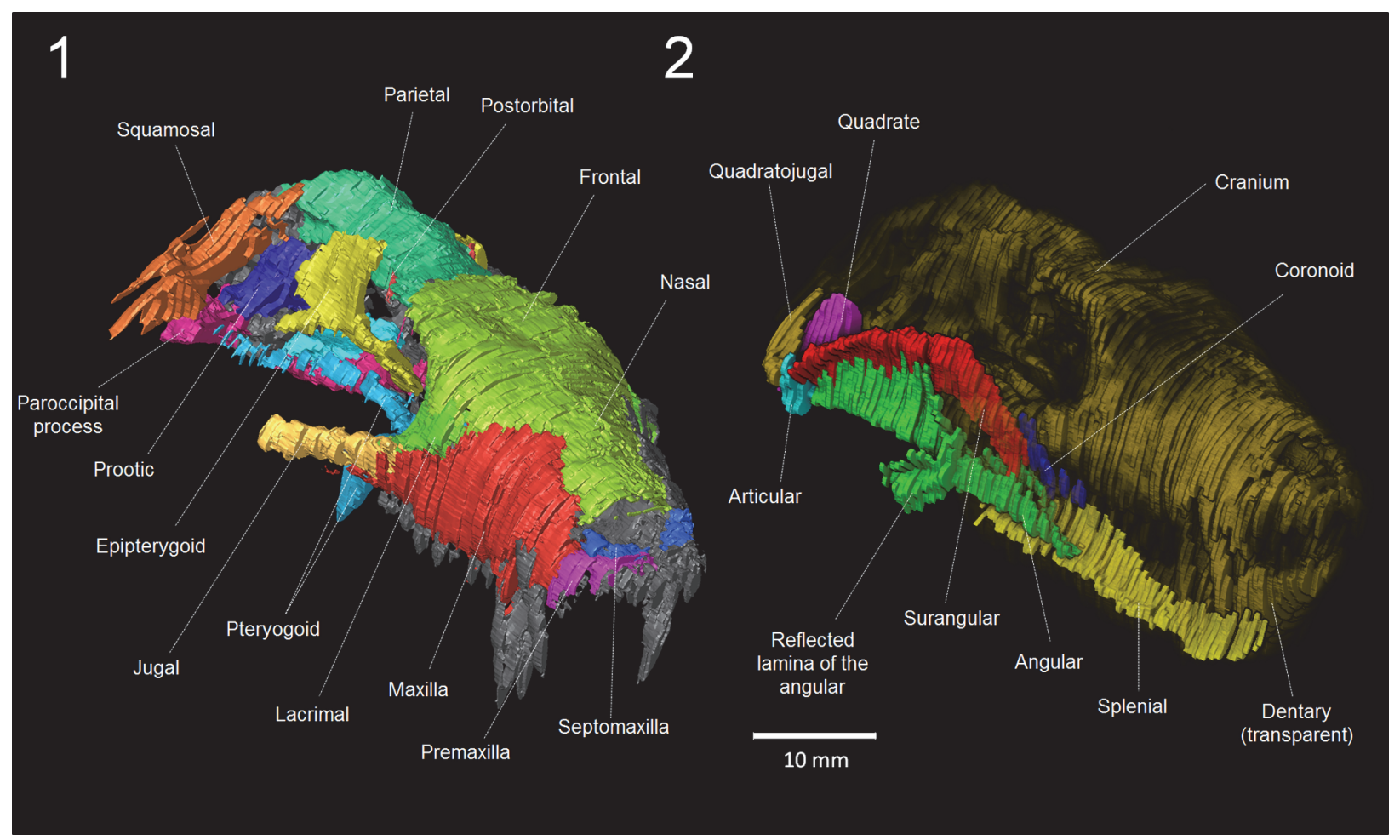

FIGURE 5. Segmentation of the skull bones of BP/1/1821, (1) in the cranium and (2) in the lower jaw. Scale bar equals $10 \mathrm{~mm}$.

ferent from one another even though the latter model was apparently reconstructed using the same serial section drawings (Appendix 1). The digital reconstruction illustrates how the wax model of $\mathrm{BP} / 1 / 1821$ would have originally looked if it was based solely on Brink's interpretations of the serial sections; however, it is apparent that some sort of smoothing was applied during or soon after the reconstruction of the wax model. The slices of wax used by Brink (1961) were $1 \mathrm{~mm}$ thick instead of the $2 \mathrm{~mm}$ that was required to reconstruct the specimen with a four times magnification. To compensate, every fifth slice was duplicated (see Brink, 1961, p. 122), which artificially increased the number of sections, giving some room for this smoothing.

Other inconsistencies, due to cosmetic improvements, are visible between both models. The morphology of the teeth is barely visible on the digital model (Figures 3,6), whereas they are well reconstructed on the wax specimen (Figure 6). For instance, the rostral-most incisors were destroyed during the grinding of the first slice, and only their roots are visible on the serial sections (Appendix 1 ). This is not reflected by the wax model (Figure 6). The wax model also bears two canines on each side while only one canine was actually preserved on the left side (Figure 6; Brink, 1961). Brink (1961) also reconstructed two canines on both sides of the skull in his figures 33B and 34. Perhaps this discrepancy exists because the caudal-most of the two canines actually has an eroded root and was in the process of being replaced by the anterior one (Appendix 1, sections 20-28; Brink, 1961, p. 125). Post-canine teeth were also sculpted on the wax specimen. They are all conical, whereas the last four should be tricuspid (Brink, 1961). Hence, the close examination of the wax model of BP/1/1821 and the re-appraisal of its anatomy in comparison with the digital model and the original description show that some of the information that was lost during the serial grinding process was reconstructed on the wax model, especially the tooth morphology. However, the main differences between the models are due to deterioration of the wax model (Figures 6, 7).

The pterygoid wings should be projecting ventrally, as depicted in the digital reconstruction (Figure 6) and the original description (Brink, 1961), but on the wax model they are nearly horizontal and oriented posteriorly (Figure 6). The slices of wax are also nearly horizontal on the pterygoid processes (Figure 7.3), which shows that this feature is due to deformation of the wax after the skull was 


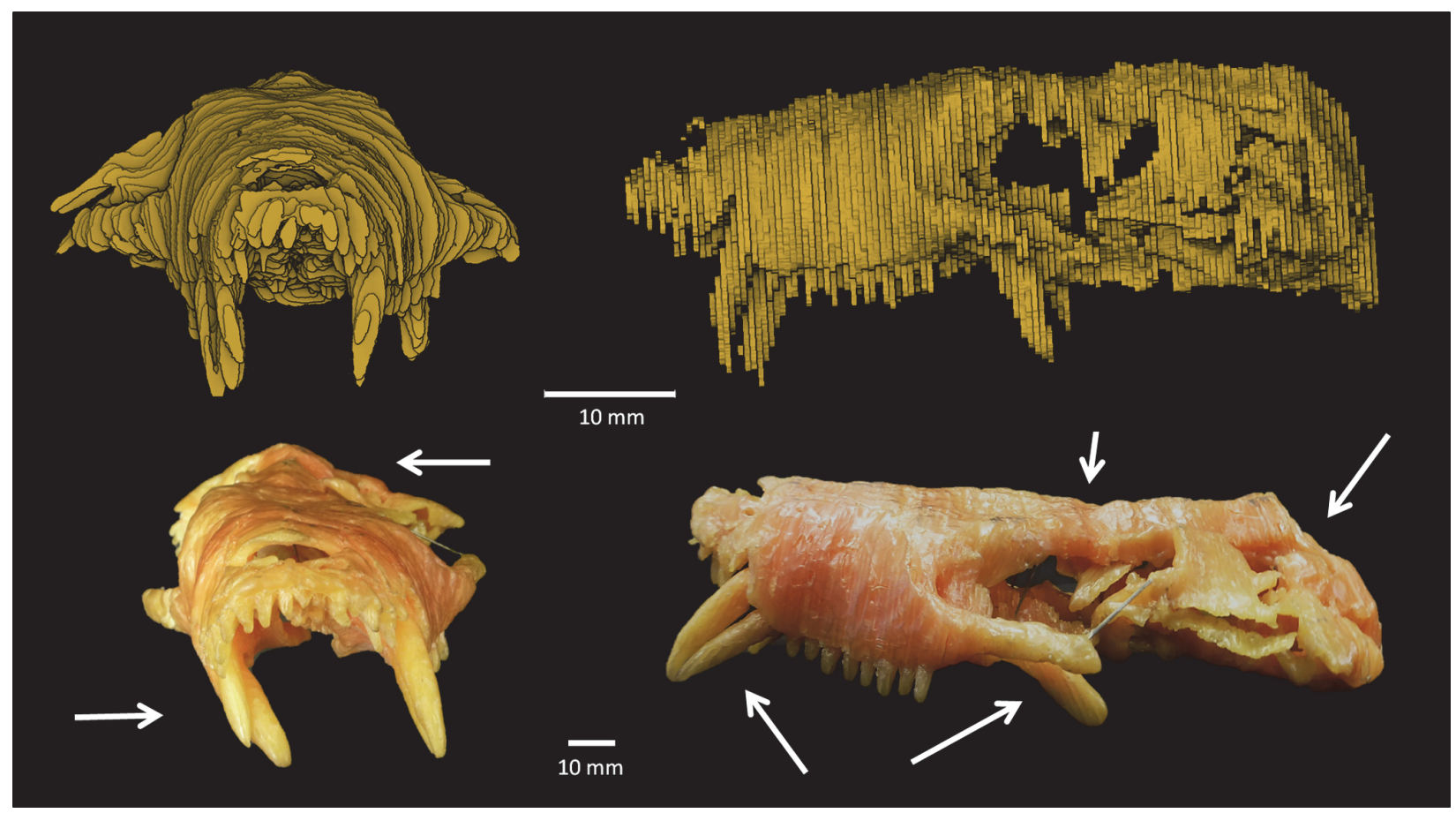

FIGURE 6. Comparison between the digital model (top) and the wax model (bottom), in rostral (left) and lateral views (right). Arrows indicate the direction of deformation of the wax model. Scale bar equals $10 \mathrm{~mm}$.

lying on its ventral side for a long period of time. The canines are also deformed in the same way (Figure 7.1). They are deflected laterally and rostrally (Figures $6,7.1$ ), which also indicates that the specimen was stored on a flat surface for a prolonged period of time. Incidentally, the rostrum is bent dorsally as it was pushed upward by the canines (Figure 6). The occipital plate and the area of the frontals, at the level of the orbits, are also collapsing (Figure 6). In addition, the whole wax model is laterally deformed when compared to the digital model (Figure 6).

Finally, some parts of the wax model are broken: the right zygoma (Figure 7.3-4), the right pterygoid process (Figure 7.3), part of the vomer (Figure 7.2), and the left mandible (Figure 7.5). Also, the reflected laminae of the angular are more pronounced on the digital model (Figures 3.1-2, 5.2) than on the wax model (Figure 7.7), presumably because they were broken on the latter. However, no pieces of these broken parts were found in the specimen's box. Eight nails and metallic sticks had been added to scaffold the wax, one in each zygoma (Figure 7.3), two inside each orbit (Figure 7.4), and one to hold each of the delicate quadrate process of the pterygoid (Figure 7.3). They were inserted inside the wax perhaps to prevent the model from collapsing in on itself. Six additional nails and sticks are also present in the jaws, two between each mandible (Figure 7.5) and two inside each ascending ramus (Figure 7.6). We are confident that these nails and sticks were inserted inside the wax after the model had been reconstructed because: i) distinct traces of melting that have erased the limit between wax slices proves that the insertion of the nails was not synchronous with the construction of the model (Figure 7.6), and ii) because Brink (1961, p. 121) stated that such supports were absent from the original reconstruction: "Although it was necessary to use supports in the process of reconstruction, the final product is entirely free from such supports. Such supports that were used were lengths or plates cut from the wax. On completion of the model all supports could be removed and the product is so stable that is it virtually like handling a modern mammalian skull." The presence of this nail scaffolding suggests that the wax was restored at some point; however, it was impossible for us to determine exactly when.

\section{DISCUSSION}

\section{Significance for Research}

The number of X-ray scanning and other nondestructive computer assisted tomographic studies (CT scan) of fossil vertebrates has greatly increased in the past 20 years, and the study of internal structures (e.g., palaeoneurology, bone 


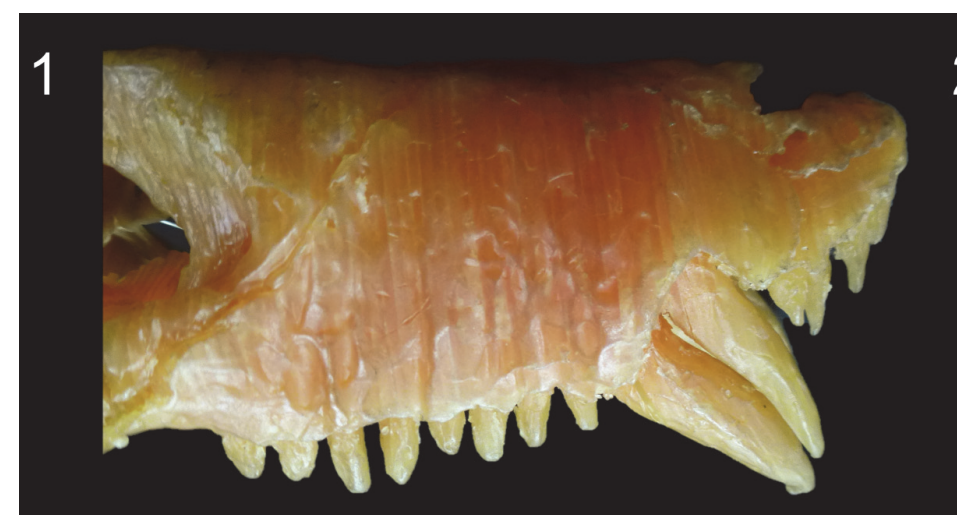

3

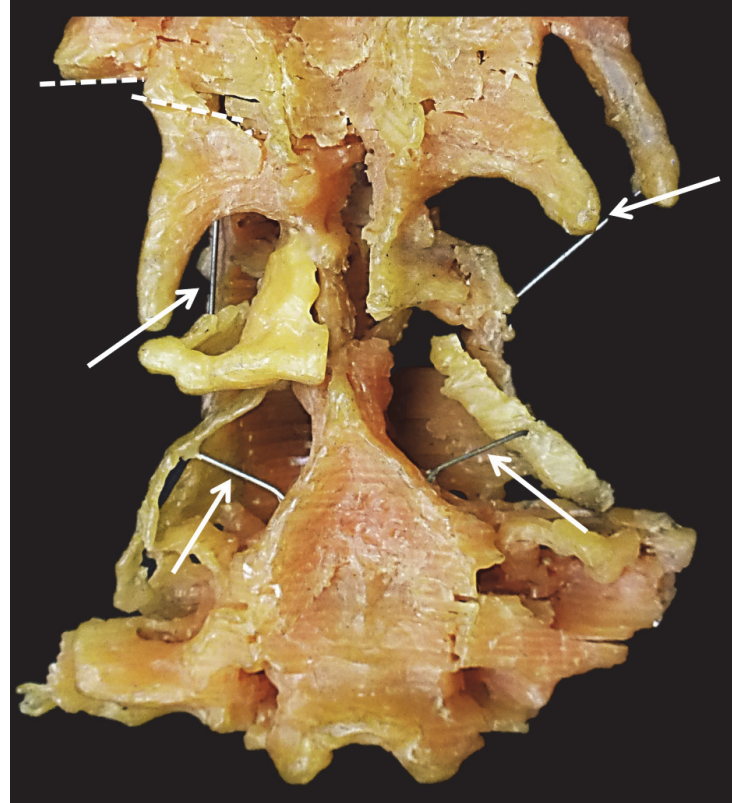

5

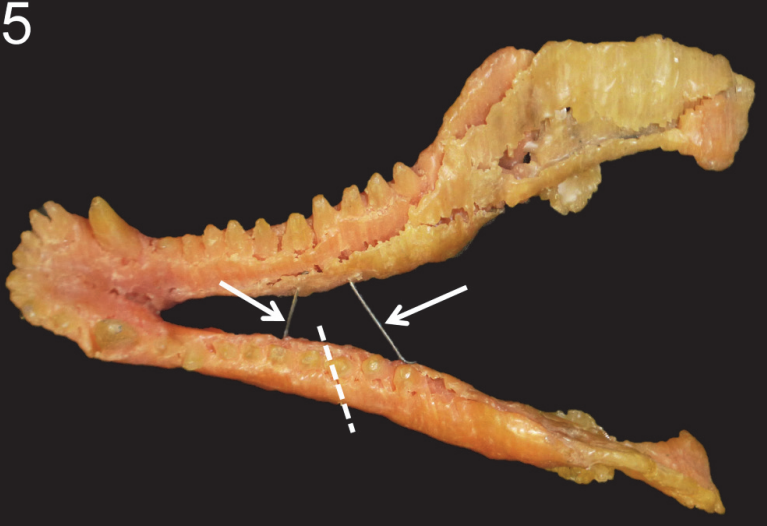

\section{4}

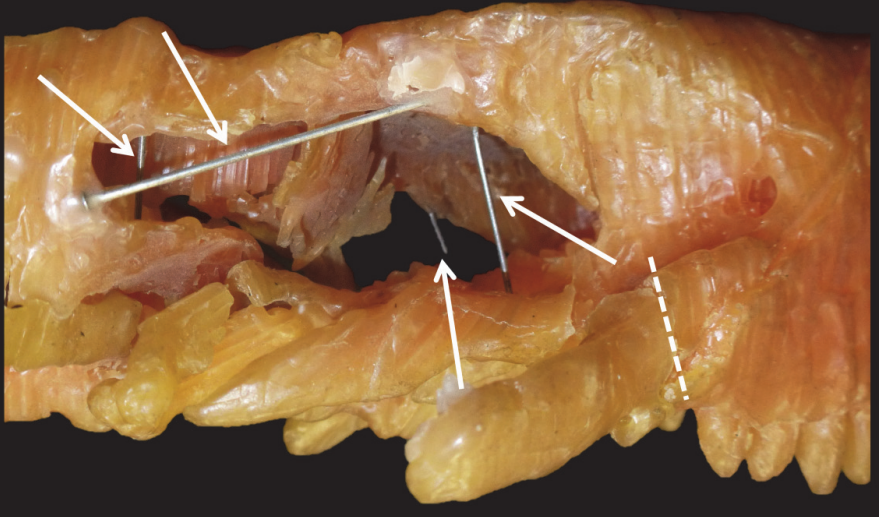

6

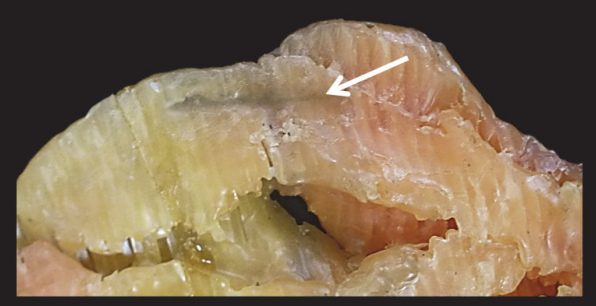

7

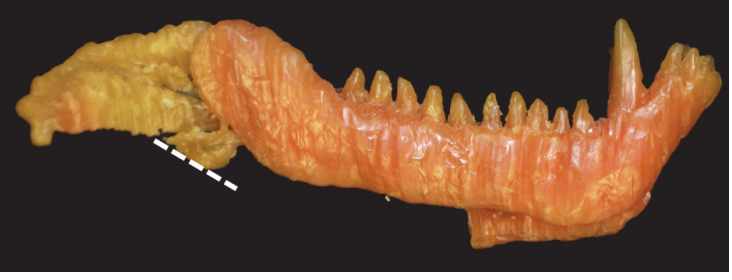

FIGURE 7. The state of preservation of the wax model of BP/1/1821. 1, the right side of the snout showing the deformation of the canine; 2 , the palate showing the broken vomer; 3 , the basicranium showing multiple cracks, nails and sticks around the pterygoid; 4 , view of the right orbit showing multiple cracks, nails and sticks; 5 , dorsal view of the of the mandible showing multiple cracks, nails and sticks; 6 , detail of the inner side of the left ascending ramus of the mandible showing a stick embedded in the wax; and 7, lateral view of the mandible showing the incomplete reflected lamina of the angular. The arrows point to the nails, dotted lines demarcate the cracks. Not to scale. 
histology) in vertebrate palaeontology has entered a new Golden Age (see Sutton, 2008; Witmer et al., 2008; and Cunningham et al., 2014 for reviews). In this context, data such as those available from old SGT sections are still valued as they contain important information about the internal structures of fossils that can supplement observations based on CT scans. Figure 5 illustrates how much valuable data can still be extracted from this kind of serial section, which is particularly significant given the number of published SGT sections that are available in the literature. For example, the following cranial studies of South African therapsids have published SGT sections and drawings or photographs of the sections that might still be available in collections: dicynodonts (Sollas and Sollas, 1914; Keyser, 1975; Fourie, 1993), dinocephalians (Boonstra, 1968), gorgonopsians (Olson, 1938b); therocephalians (Olson, 1938a; Maier and van den Heever, 2002; Sigurdsen, 2006), and cynodonts (Broom, 1938; Rigney, 1938; Fourie, 1974). As we found discrepancies between some of Brink's labels in his published sections (Brink, 1961, figure 35) and our interpretation of his original drawings, it is important to have access to the full series of hand-drawn tomograms so that reinterpretation can be implemented. In addition, the physical slices made using a microtome or grinding and peel techniques of some therapsid skulls are also housed in the fossil collections in South Africa, e.g., the Lystrosaurus skulls sectioned by Cluver (1971) at the Iziko South African Museum, the snout of a Diademodon sectioned by Grine (1978) at the ESI, or the skull of a Glanosuchus sectioned by Maier and van den Heever (2002) at the Department of Zoology of the University of Stellenbosch. Other fossil therapsids housed elsewhere in the world include, for example, the 'Anomodont A' sectioned by Olson (Olson, 1937, 1944; Angielczyk et al., 2016) and a young Galesaurus sectioned by Rigney (1938) at the Field Museum in Chicago. These fossil sections can be photographed and digitized to produce new 3D models of the oncecomplete specimen and can be used or re-analyzed for research with no additional cost, time, or space requirements. Interestingly enough, using a similar technique described here, an intriguing anomodont skull serially sectioned by Olson in 1937 was partially reconstructed in order to identify it and perform a revision of Brachyprosopus broomi (Angielczyk et al., 2016).

The data produced from SGT studies should be valued as much as possible since specimens were sacrificed for them. As exemplified by Jasi- noski et al. (2015) and Benoit et al. (2015), data from SGT studies like those of Fourie (1974) are still relevant and often cited. There is also a flourishing literature in invertebrate palaeontology illustrating how SGT data is useful for various fields such as the study of soft tissue structures (e.g., Sutton et al., 2005, 2006; Siveter et al., 2003, 2013), systematic and phylogenetic analyses (e.g., Sutton et al., 2002, 2005; Siveter et al., 2004, 2007a; Briggs et al., 2004, 2012), palaeoenvironmental reconstruction (e.g., Lukeneder and Weber, 2014) or to infer behaviour in extinct species (e.g., Siveter et al., 2007b). The serial grinding, digital photography, and computerized restoration of the beautifully preserved Silurian fauna of the Herefordshire deposit have allowed the virtual dissection of several key invertebrate specimens in exquisite detail, which brought a new insight into the early radiation and palaeobiology of arthropods, brachiopods, and molluscs (Sutton et al., 2001, 2005, 2006; Briggs et al., 2004, 2012; Siveter et al., 2003, 2007a, b, 2013).

Computer assisted tomography is still a relatively expensive technique in terms of specialized software and hardware, and the time and technical skill required to process the data (Sutton, 2008; Cunningham et al., 2014). Moreover, there are features that some CT scanning techniques cannot detect, such as phase contrast (i.e., contrast between the matrix infilling of two different internal structures) that is invisible to conventional X-ray sources and can only be detected by synchrotron beam or serial grinding tomography (Tafforeau et al., 2006; Sutton, 2008; Cunningham et al., 2014). Large and dense specimens often lack the appropriate resolution and appear opaque on scans, except when using neutron-rays (which can make the specimen radioactive) or using SGT (Maier and van den Heever, 2002; Schwarz et al., 2005; Tafforeau et al., 2006; Sutton, 2008; Cunningham et al., 2014; Laaß and Schillinger, 2015). Lastly, sometimes the specimens simply have insufficient contrast on CT scans while SGT offers direct access to the internal structure (Maier and van den Heever, 2002; see Cunningham et al., 2014). This is what happened with the invertebrate fossils from the Herefordshire deposit, which are preserved in calcite that is very similar to the micritic host rock (Sutton et al., 2001; Sutton, 2008; Cunningham et al., 2014). The fossils are difficult to prepare by the usual mechanical and chemical means, and X-ray techniques cannot discriminate between the matrix and the fossils (Sutton et al., 2001; Sutton, 2008; Cunningham et al., 2014). In this particular case, 
SGT accompanied with digital photography of the sections and digital restoration proved to be the most effective way to access the morphology of the fossils (Sutton et al., 2001, 2005, 2006; Briggs et al., 2004, 2012; Siveter et al., 2003, 2007a, 2007b, 2013; Sutton, 2008).

\section{Significance for Curation and Archiving}

Fifty-five years ago, Brink (1961) created a wax model of BP/1/1821 without the need for support structures, but the presence of metal sticks and nails indicates that over time it has collapsed on itself. Further evidence of this process of degradation is visible today through the dramatic deformation of the wax model in comparison to its digital counterpart that is based on Brink's tomograms (Figure 6). Wax is very sensitive to temperature variations and the wax model has no internal sediment filling, which makes it very susceptible to damage during physical handling. The digital reconstruction based on Brink's drawings of the raw serial sections show that the wax model deteriorated relatively quickly and, apart from the description (Brink, 1961), it is all that testifies to the morphology of the original specimen. What remains of the wax model of BP/1/1821 could be preserved through digitization using surface scanning, but the internal anatomy of the specimen would not be recorded. The use of X-ray scanning is excluded because of the low absorbance of the wax compared to the metallic sticks, which would not give enough contrast and would create artifacts on the radiographs. Moreover, the heat produced by the engine could further damage the wax. As such, digitization of Brink's drawings in order to reconstruct the specimen in silico seems to be the most effective and easiest way to represent his interpretations of the original fossil. This is certainly the most important step for curation of the drawings, as they are also deteriorating (the paper is yellowish and the pencil marks are fading away). With the re-discovery of these drawings, it became possible to reconstruct a digital model that revealed how the wax model was affected by the vicissitudes of time (Figure 6).

The recreation of a model of BP/1/1821 in silico highlights three new opportunities for future conservation efforts: first, as a substitute to the wax model, a digital model offers fewer problems in terms of preservation since the quality of the digitized drawing and reconstruction will not decline with time or manipulations (however questions of data standardization, computer power, ethics, costs, and the implementation of sustainable, long- term digital archiving still remain important issues for digital palaeontological data; see Gilbert and Carlson, 2011; Mallison, 2011; and Cunningham et al., 2014 for a complete discussion). Second, a new model was 3D-printed in resin, and could be printed again at any time using any 3D printer. In contrast to the wax model, this model is the same size as the original (although this can easily be adjusted during printing), and its morphology accurately reflects that illustrated in Brink's drawings of the serial sections (Figure 4). Lastly, a 3D-printed model can serve as a guide for the future restoration of the wax model. Nevertheless, one should keep in mind that Brink's drawing are subjective and thus our new digital reconstruction, like the original wax model, is based on an interpretative medium and will never replace the lost specimen.

\section{CONCLUDING REMARKS}

Here we provide an easy and affordable technique that assisted us to reconstruct BP/1/1821 from serial section drawings of the 55 year old holotype of the formerly recognised species 'Scalopocynodon gracilis'. This study illustrates the value of old original drawings/ photographs of SGT sections and peels which should not be neglected. Conservation of these data through digitization (e.g., scanning, digital photography) should be a priority, as they can provide important new perspectives to long destroyed specimens. In the case of $\mathrm{BP} / 1 / 1821$, this technique has provided a tool to assess the state of preservation of the old wax model. To archive a digital copy of these drawings is therefore as important as curating original fossil specimens. If photographic plates (e.g., Sollas and Sollas, 1914), physical sections (e.g., Cluver, 1971), peels (e.g., Angielczyk et al., 2016), or drawings (e.g., Brink, 1961) are housed in collections, then these items should be appropriately accessioned and linked to the record of the source fossil. Attempts to digitize them should be undertaken, and original notes from the studied specimen should also be located and subsequently preserved. In addition, SGT data in vertebrate palaeontology has recently been overlooked because of the advent of non-destructive digital tomography (Cunningham et al., 2014). However, data already acquired could still potentially prove useful for modern comparative works and enable internal anatomical detail of a given fossil species at no additional cost.

What happened to specimen BP/1/1821 is not an isolated case. According to Thackeray et al. (1998), the holotype skull of Lystrosaurus murrayi 
was sectioned by Huxley in 1859. At that time, scanning techniques did not exist, but more recently, the holotype of Stygimoloch spinifer was sectioned in order to study the cranial ontogeny in pachycephalosaurids (Horner and Goodwin, 2009). Among invertebrates, many holotypes from the Herefordshire locality underwent serial grinding because anatomical details were only accessible through this method (e.g., Sutton et al., 2002, 2005; Briggs et al., 2004, 2012; Siveter et al., 2007a); however, even in this particular case, optical non-destructive tomographic techniques (e.g., synchrotron and CT scanning) might produce valuable results (Sutton, 2008; Siveter et al., 2014). Serial grinding and sectioning can still be useful techniques to study fossil anatomy and evolutionary processes (e.g., Maier and van den Heever, 2002; Sigurdsen, 2006), but we recommend performing X-ray, neutron, or surface scanning of the specimens before sectioning in order to retain a digital copy of the original (just like Maier and van den Heever [2002] did for their specimen of Glanosuchus). Destruction of a specimen, particularly a holotype, must remain a last resort, as this threatens the very premise of the taxonomic endeavour and, given the rapidly changing technological landscape, prevents future analysis.

\section{ACKNOWLEDGMENTS}

The authors would like to thank Kudawashe Jakata for assisting with printing of the specimen. We also thank B. Zipfel, curator of the palaeontological collections of the Evolutionary Studies Institute (University of the Witwatersrand, Johannesburg), the assistant curator S. Jirah, and B.S. Rubidge for their help and access to the collections of the ESI. The authors also thank the two anonymous reviewers for their help to improve the manuscript. This research was conducted with financial support from PAST and its scatterlings projects; the NRF; and DST/NRF Centre of Excellence in Palaeosciences.

\section{REFERENCES}

Angielczyk, K.D., Rubidge, B.S., Day, M.O., and Lin, F. 2016. A Reevaluation of Brachyprosopus broomi and Chelydontops altidentalis, Dicynodonts (Therapsida, Anomodontia) from the Middle Permian Tapinocephalus Assemblage Zone of the Karoo Basin, South Africa. Journal of Vertebrate Paleontology, 36(2):e1078342.

Benoit, J., Abdala, F., Van den Brandt, M.J., Manger, P.R., and Rubidge, B.S. 2015. Physiological implications of the abnormal absence of the parietal foramen in a Late Permian cynodont (Therapsida). The Science of Nature (Naturwissenschaften), 102:69.

Benoit, J., Ben Haj Ali, M., Adnet, S., El Mabrouk, E., Hayet, K., Marivaux, L., Merzeraud, G., Merigeaud, S., Vianey-Liaud, M., and Tabuce, R. 2013a. Cranial remain from Tunisia provides new clues for the origin and evolution of Sirenia (Mammalia, Afrotheria) in Africa. PLoS ONE, 8:e54307.

Benoit, J., Merigeaud, S., and Tabuce, R. 2013b. Homoplasy in the ear region of Tethytheria and the systematic position of Embrithopoda (Mammalia, Afrotheria). Geobios, 46:357-370.

Boonstra, L.D. 1968. The braincase, basicranial axis and median septum in the Dinocephalia. Annals of the South African Museum, 50:195-273.

Branco, W. 1906. Die Anwendung der Rontgenstrahlen in der Palaontologie. Abhandlungen der Koniglich Preussischen Akademie der Wissenschaften, Verlag der Koniglichen Akademie der Wissenschaften. (In German)

Briggs, D.E.G., Sutton, M.D., Siveter, D.J., and Siveter, D.J. 2004. A new phyllocarid (Crustacea: Malacostraca) from the Silurian Fossil-Lagerstätte of Herefordshire, UK. Proceedings of the Royal Society B: Biological Sciences, 271:131-138.

Briggs, D.E.G., Siveter, D.J., Siveter, D.J., Sutton, M.D., Garwood, R.J., and Legg, D.A. 2012. A Silurian horseshoe crab illuminates the evolution of arthropod limbs. Proceedings of the National Academy of Science, USA, 109:15702-15705.

Brink, A.S. 1961. A new type of primitive cynodont. Palaeontologia Africana, 7:119-154.

Broom, R. 1938. On the structure of the skull of the cynodont, Thrinaxodon liorhinus, Seeley. Annals of the Transvaal Museum, 19:263-269.

Case, E.C. 1914. On the structure of the inner ear in two primitive reptiles. Biological Bulletin, 27:213-216.

Cluver, M.A. 1971. The cranial morphology of the dicynodont genus Lystrosaurus. Annals of the South African Museum, 56:155-274.

Conroy, G.C. and Vannier, M.W. 1984. Noninvasive three-dimensional computer imaging of matrix-filled fossil skulls by high-resolution computed tomography. Science, 226:1236-1239.

Cox, C.B. 1962. A natural cast of the inner ear of a dicynodont. American Museum Novitates, 2116:1-6.

Court, N. 1992. Cochlea anatomy of Numidotherium koholense: auditory acuity in the oldest known proboscidean. Lethaia, 25:211-215.

Cunningham, J.A., Rahman, I.A., Lautenschlager, S., Rayfield, E.J., and Donoghue, P.D.J. 2014. Virtual world of paleontology. Trends in Ecology and Evolution, 29:347-357.

Dart, R.A. 1925. Australopithecus africanus: the manape of South Africa. Nature, 115:195-199.

Dechaseaux, C. 1974. Artiodactyles primitifs des Phosphorites du Quercy. Annales de Paléontologie, 60:59-100. (In French) 
Fourie, S. 1974. The cranial morphology of Thrinaxodon liorhinus Seeley. Annals of the South African Museum, 65:337-400.

Fourie, H. 1993. A detailed description of the internal structure of the skull of Emydops (Therapsida: Dicynodontia). Palaeontologia Africana, 30:103-111.

Gilbert, H. and Carlson, J. 2011. Data models and global data integration in paleoanthropology: A plea for specimen-based data collection and management. p. 111-121. In Macchiarelli, R. and Weniger, G.-C. (eds.), Pleistocene Databases: Acquisition, Storing, Sharing. Neanderthal Museum, Mettmann.

Gould, S.J. 1989. Wonderful Life. The Burgess Shale and the Nature of History. W.W. Norton and Company, New York.

Grine, F.E. 1978. Notes on a specimen of Diademodon previously referred to Cyclogomphodon. Palaeontologia Africana, 21:167-174.

Hopson, J.A. and Kitching, J.W. 1972. A revised classification of cynodonts (Reptilia; Therapsida). Palaeontologia Africana, 14:71-85.

Horner, J.R. and Goodwin, M.B. 2009. Extreme Cranial Ontogeny in the Upper Cretaceous Dinosaur Pachycephalosaurus. PLoS ONE, 4(10):e7626.

ICZN 1999. International Code of Zoological Nomenclature, 4th Edition. International Trust for Zoological Nomenclature, London.

Jarvik, E. 1942. On the structure of the snout of crossopterygians and lower gnathostomes in general. Zoologiska Bidrag från Uppsala, 21:235-675.

Jarvik, E. 1954. On the visceral skeleton in Eusthenopteron with a discussion of the parasphenoid and palatoquadrate in fishes. Kungliga Svenska Vetenskapsakademiens Handlingar, 5:1-104.

Jasinoski, S.C., Abdala, F., and Fernandez, V. 2015. Ontogeny of the Early Triassic cynodont Thrinaxodon liorhinus (Therapsida): Cranial morphology. Anatomical Record, 298:1440-1464.

Jerison, H.J. 1973. Evolution of the Brain and Intelligence. Academic Press, New York.

Kemp, T.S. 1979. The primitive cynodont Procynosuchus: functional anatomy of skull and relationships. Philosophical Transactions of the Royal Society of London, Series B, 285:73-122.

Kermack, D.M. 1970. True serial-sectioning of fossil material. Biological Journal of the Linnean Society, 2:47-53.

Keyser, A.W. 1975. A re-evaluation of the cranial morphology and systematics of some tuskless Anomodontia. Memoirs of the Geological Survey of South Africa, 67:1-110.

Kielan-Jaworowska, Z., Cifelli, R.L., and Luo, Z.-X. 2004. Mammals from the Age of Dinosaurs Origins, Evolution, and Structure. Columbia University Press, New York.

Kielan-Jaworowska, Z., Presley, R., and Poplin, C. 1986. The cranial vascular system in taeniolabidoid multituberculate mammals. Philosophical Transactions of the Royal Society B, Biological Sciences, 313:525602.

King, G.M. and Rubidge, B.S. 1993. A taxonomic revision of small dicynodonts with postcanine teeth. Zoological Journal of the Linnean Society, 107:131-154.

Laaß, M. and Schillinger, B. 2015. Reconstructing the Auditory Apparatus of Therapsids by Means of Neutron Tomography. Physics Procedia, 69:628-635.

Lukeneder, A. and Weber, G.W. 2014. Computed reconstruction of spatial ammonoid-shell orientation captured from digitized grinding and landmark data. Computers \& Geosciences, 64:104-114.

Luo, Z.-X. and Eastman, E.R. 1995. Petrosal and inner ear of a squalodontoid whale: implications for evolution of hearing in Odontocetes. Journal of Vertebrate Paleontology, 15:431-442.

Maier, W. and van den Heever, J. 2002. Middle ear structures in the Permian Glanosuchus sp. (Therocephalia, Therapsida), based on thin sections. Fossil Record, 5:309-318.

Mallison, H. 2011. Digitizing methods for paleontology applications, benefits and limitations. p. 7-44. In Elewa, A.M.T. (ed.), Computational Paleontology. Springer-Verlag, Berlin, Heidelberg.

Olson, E. C. 1937. The skull structure of a new anomodont. Journal of Geology, 45:851-858.

Olson, E.C. 1938a. Notes on the brain case of a therocephalian. Journal of Morphology, 63:75-86.

Olson, E.C. 1938b. The occipital, otic, basicranial and pterygoid regions of the Gorgonopsia. Journal of Morphology, 62:141-175.

Olson, E.C. 1944. Origin of mammals based upon cranial morphology of the therapsid suborders. Geological Society of America, Special Papers, 55:1-136.

Quiroga, J.C. 1984. The endocranial cast of the advanced mammal-like reptile Therioherpeton cargnini (Therapsida-Cynodontia) from the Middle Triassic of Brazil. Journal fuer Hirnforschung, 25:285290.

Rigney, H.W. 1938. The morphology of the skull of a young Galesaurus planiceps and related forms. Journal of Morphology, 63:491-529.

Rubidge, B.S. and Sidor, C.A. 2001. Evolutionary patterns among Permo-Triassic Therapsids. Annual Review of Ecology and Systematics, 32:449-480.

Schindelin, J., Arganda-Carreras, I., Frise, E., Kaynig, V., Longair, M., Pietzsch, T., Preibisch, S., Rueden, C., Saalfeld, S., Schmid, B., Tinevez, J.-Y., White, D.J., Hartenstein, V., Eliceiri, K., Tomancak, P., and Cardona, P. 2012. Fiji: an open-source platform for biological-image analysis. Nature Methods, 9:676-682.

Schwarz, D., Vontobel, P.L., Eberhard, H., Meyer, C.A., and Bongartz, G. 2005. Neutron tomography of internal structures of vertebrate remains: a comparison with X-ray computed tomography. Paleontologia Electronica, 8.2.30A:1-11 palaeo-electronica.org/2005_2/neutron/ issue2_05.htm 
Sigurdsen, T. 2006. New features of the snout and orbit of a therocephalian therapsid from South Africa. Acta Palaeontologica Polonica, 51:63-75.

Sigurdsen, T., Huttenlocker, A., Modesto, S.P., Rowe, T.B., and Damiani, R. 2012. Reassessment of the morphology and paleobiology of the therocephalian Tetracynodon darti (Therapsida), and the phylogenetic relationships of Baurioidea. Journal of Vertebrate Paleontology, 32:1113-1134.

Simpson, G.G. 1933. A simplified serial sectioning technique for the study of fossils. American Museum Novitates, 634:1-6.

Siveter, D.J., Briggs, D.E.G, Siveter, D.J., Sutton, M.D., and Joomun, S.C. 2013. A Silurian myodocope with preserved soft-parts: cautioning the interpretation of the shell-based ostracod record. Proceedings of the Royal Society B, Biological Sciences, 280:20122664.

Siveter, D.J., Siveter, D.J., Sutton, M.D., and Briggs, D.E. 2007b. Brood care in a Silurian ostracod. Proceedings of the Royal Society B, Biological Sciences, 274:465-469.

Siveter, D.J., Sutton, M.D., Briggs, D.E.G., and Siveter, D.J. 2003. An ostracode crustacean with soft parts from the Lower Silurian. Science, 302:1749-1751.

Siveter, D.J., Sutton, M.D., Briggs, D.E.G., and Siveter, D.J. 2004. A Silurian sea spider. Nature, 431:978980.

Siveter, D.J., Sutton, M.D., Briggs, D.E.G., and Siveter, D.J. 2007a. A new probable stem lineage crustacean with three-dimensionally preserved soft parts from the Herefordshire (Silurian) Lagerstatte, UK. Proceedings of the Royal Society B, Biological Sciences, 274:2099-2107.

Siveter, D.J., Tanaka, T., Farrell, U.C., Martin, M.J., Siveter, D.J., and Briggs D.E.G. 2014. Exceptionally preserved 450-Million-Year-Old Ordovician ostracods with brood care. Current Biology, 24:801-806.

Sollas, W.J. 1904. A method for the investigation of fossils by serial sections. Philosophical Transactions of the Royal Society of London, Series B, 196:257-263

Sollas, I.B.J. and Sollas, W.J. 1914. A study of the skull of a Dicynodon by means of serial sections. Philosophical Transactions of the Royal Society of London, Series B, 204:201-225.

Stensiö, E.A. 1927. The Downtonian and Devonian vertebrates of Spitsbergen. Part I. Family Cephalaspidae. Skrifter Svalbard Nordishavet, 12:1-391.
Sutton, M.D. 2008. Tomographic techniques for the study of exceptionally preserved fossils. Proceedings of the Royal Society B, Biological Sciences, 275:1587-1593.

Sutton, M.D., Briggs, D.E.G., Siveter, D.J., and Siveter, D.J. 2001. Methodologies for the visualization and reconstruction of three-dimensional fossils from the Silurian Herefordshire Lagerstätte. Palaeontologia Electronica, 4.1.1:1-17

palaeo-electronica.org/2001_1/s2/issue1_01

Sutton, M.D., Briggs, D.E.G., Siveter, D.J., and Siveter, D.J. 2005. Silurian brachiopods with soft-tissue preservation. Nature, 436:1013-1015.

Sutton, M.D., Briggs, D.E.G., Siveter, D.J., and Siveter, D.J. 2006. Fossilized soft tissues in a Silurian platyceratid gastropod. Proceedings of the Royal Society B, Biological Sciences, 273:1039-1044.

Sutton, M.D., Briggs, D.E.G., Siveter, D.J., Siveter, D.J., and Orr, P.J. 2002. The arthropod Offacolus kingi (Chelicerata) from the Silurian of Herefordshire, England: computer based morphological reconstructions and phylogenetic affinities. Proceedings of the Royal Society B, Biological Sciences, 269:11951203.

Tafforeau, P., Boistel, R., Boller, E., Bravin, A., Brunet, M., Chaimanee, Y., Cloetens, P., Feist, M., Hoszowska, J., Jaeger, J.-J., Kay, R.F., Lazzari, V., Marivaux, L., Nel, A., Nemoz C., Thibault, X., Vignaud, P., and Zabler, S. 2006. Applications of X-ray synchrotron microtomography for non-destructive 3D studies of paleontological specimens. Applied Physics A, 83:195-202.

Thackeray, J.F., Durand, J.F., and Meyer, L. 1998. Morphometric analysis of South African dicynodonts attributed to Lystrosaurus murrayi (Huxley, 1859) and L. declivis (Owen, 1860): probabilities of conspecificity. Annals of the Transvaal Museum, 36:413-420.

Whitmore, F.C. 1953. Cranial morphology of some Oligocene Artiodactyla. Geological Survey Professional Paper, 243:1-159.

Witmer, L.M., Ridgely, R.C., Dufeau, D.L., and Semones, M.C. 2008. Using CT to peer into the past: 3D visualization of the brain and ear regions of birds, crocodiles, and nonavian dinosaurs, p. 67-88. In Endo, $\mathrm{H}$. and Frey, R. (eds.), Anatomical Imaging: Towards a New Morphology. Springer Verlag, Tokyo. 


\section{APPENDIX 1.}

Movie of the aligned serial section drawings of BP/1/1821 made by A.S. Brink. The 116 sections represent the entire specimen. Note that Brink numbered the sections from 1 to 118 because he missed number 83 and duplicated 110; however Brink also labelled every section with the corresponding $0.5 \mathrm{~mm}$ interval so we are confident that no section is missing. Because of this mislabelling, the section numbers in the movie are shifted between 83 and 110 with respect to Brink's numbered sections (see Brink, 1961, figure 35). See:

palaeo-electronica.org/content/2016/1478-reconstructing-scalopocynodon
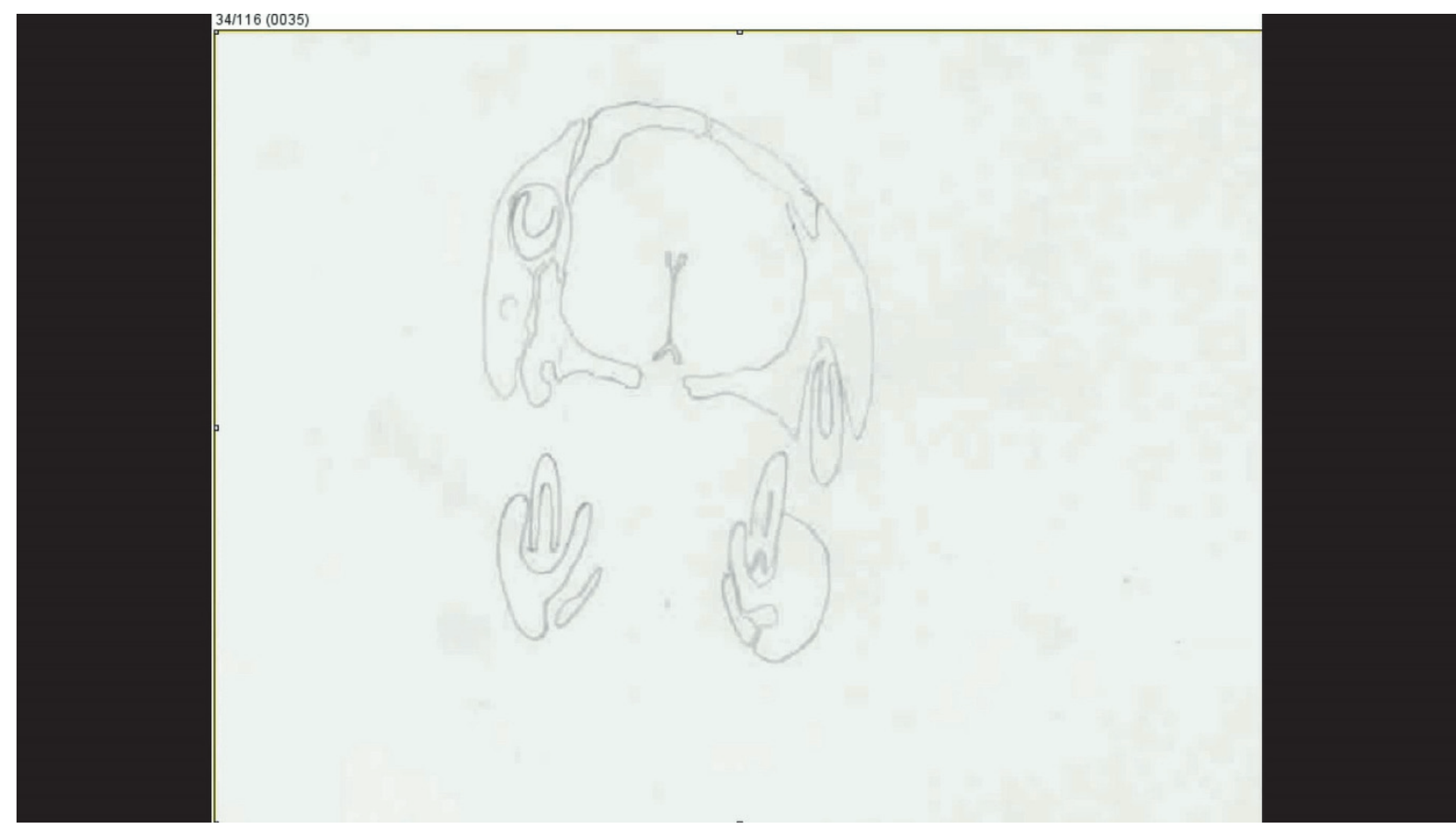


\section{APPENDIX 2.}

Movie of the virtual 3D model of $\mathrm{BP} / 1 / 1821$ that was reconstructed from the drawings made by A.S. Brink (1961). See:

palaeo-electronica.org/content/2016/1478-reconstructing-scalopocynodon

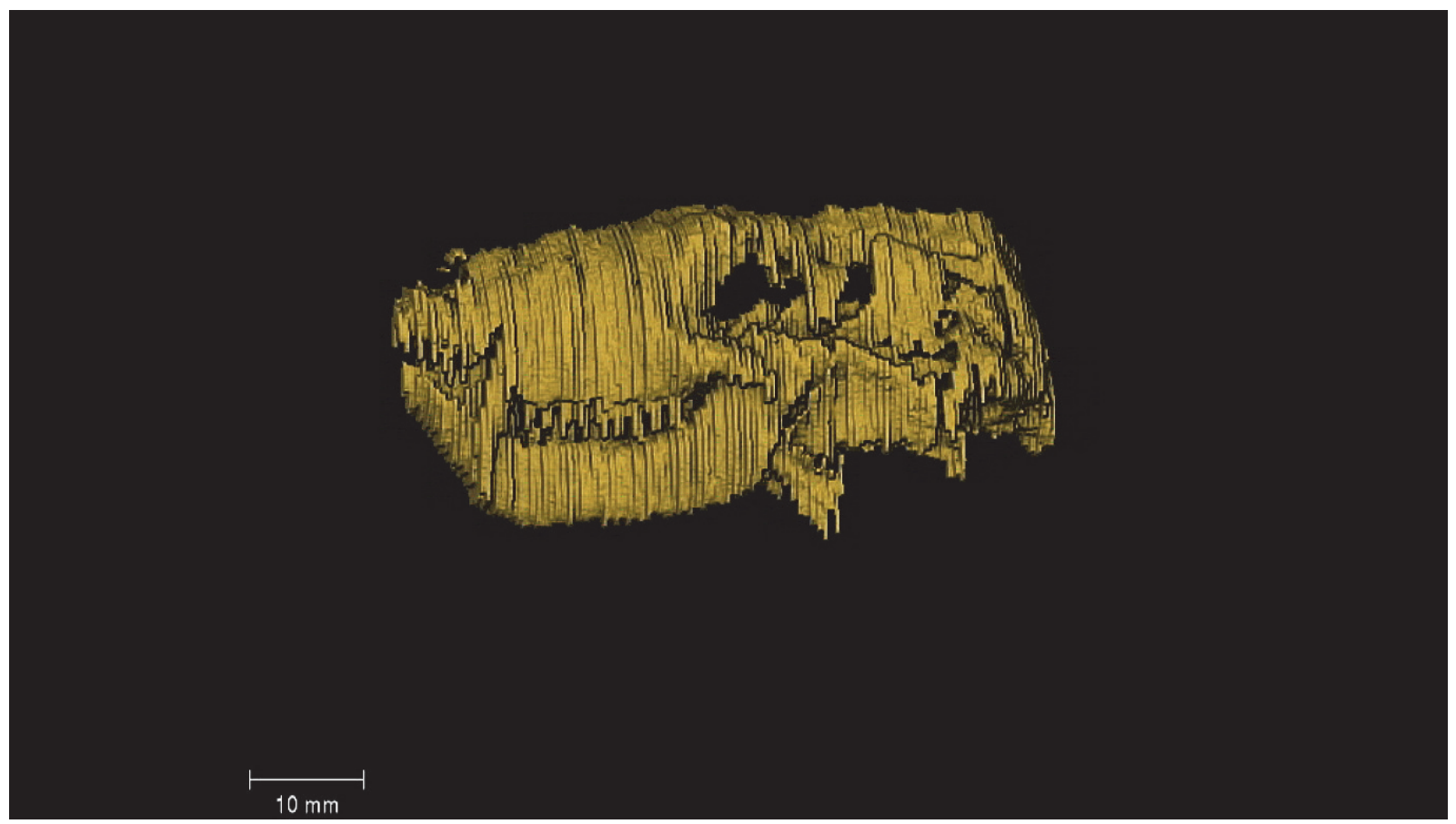

